\title{
Hubungan Antara Kematangan Emosi dan Religiusitas dengan Penyesuaian Diri pada Menantu Perempuan yang Tinggal dengan Ibu Mertua
}

\author{
Vika Mandasari ${ }^{1}$ \\ Fakultas Psikologi, Program Studi Psikologi, Universitas Muria Kudus \\ vika.mandasari05@gmail.com \\ Latifah Nur Ahyani ${ }^{2}$ \\ Fakultas Psikologi, Universitas Muria Kudus \\ latifah.nur@umk.ac.id \\ Fajar Kawuryan ${ }^{3}$ \\ Fakultas Psikologi, Universitas Muria Kudus \\ fajar.kawuryan@umk.ac.id
}

\begin{abstract}
The study aims to determine the relationship between emotional maturity and religiosity with adjustment of daughter-in-law who lives with mother-in-law. The samoling technique in this study used a quota sampling technique, with the sample of the study were 50 daughter-in-law who live with mother-in-law with a marriage age range of one to five years and they are Muslim. The measuring instruments used to obtain the data were the emotional maturity scale, the religiosity scale and the adjustment scale. The results of data analysis using the SPSS 16.0 regression analysis program for windows showed that the coefficient correlation of the three variables rx $1,2 y$ is 0,810 with a p value of 0,000 or $(p<0,01)$. Based on the results of the regression analysis, it shows that there is a very significant relationship between emotional maturity and religiosity with self adjustment. Thus the major hypothesis in this study was accepted. The results of the coefficient correlation between the emotional maturity variable with self adjustment rxly is 0,810 with a $p$ value of 0,000 or $(p<0,01)$. This means that there is a very significant positive relationship between emotional maturity with adjustment of daughter-in-law who lives with mother-in-law, thus the better the emotional maturity of the daughter in law the better her adjustment and vice versa. While the coefficient correlation between the religiosity variable with self adjustment $r x 2 y$ is 0,636 with a $p$ value 0,000 or $(p<0,01)$. This means that there is a very significant positive relationship between religiosity with adjustment of daughter-in-law who lives with mother-inlaw, thus the higher the level of religiosity of the better her adjustment and vice versa.
\end{abstract}

Keywords: Adjustment, Emotional Maturity, Religiosity 


\begin{abstract}
Abstrak
Penelitian ini bertujuan untuk mengetahui hubungan antara kematangan emosi dan religiusitas dengan penyesuaian diri pada menantu perempuan yang tinggal dengan ibu mertua. Teknik pengambilan sampel pada penelitian ini menggunakan teknik quota sampling, dengan $n=50$ menantu perempuan yang tinggal dengan ibu mertua dengan rentang usia pernikahan satu sampai lima tahun dan beragama islam. Alat ukur yang digunakan untuk memperoleh data adalah skala kematangan emosi, skala religiusitas dan skala penyesuaian diri. Hasil analisis data dengan menggunakan analisis regresi program SPSS 16.0 for windows diperoleh hasil koefisien korelasi dari ketiga variabel $\mathrm{rx} 1,2 \mathrm{y}=0,810$ dengan nilai $\mathrm{p}$ sebesar 0,000 atau $\mathrm{p}$ kurang dari 0,01. Berdasarkan hasil analisis regresi tersebut menunjukkan bahwa terdapat hubungan yang sangat signifikan antara kematangan emosi dan religiusitas dengan penyesuaian diri. Hasil koefisien korelasi antara variabel kematangan emosi dengan penyesuaian diri rxly sebesar 0,810 dengan nilai $\mathrm{p}$ sebesar 0,000 atau $\mathrm{p}$ kurang dari 0,01 . Ini berarti terdapat hubungan positif yang sangat signifikan antara kematangan emosi dengan penyesuaian diri pada menantu perempuan yang tinggal dengan ibu mertua, dengan demikian semakin baik kematangan emosi menantu perempuan semakin baik penyesuaian dirinya begitu pula sebaliknya. Sedangkan koefisien korelasi antara variabel religiusitas dengan penyesuaian diri rx $2 \mathrm{y}$ sebesar 0,636 dengan nilai $p$ sebesar $0,000 \mathrm{p}$ kurang dari 0,01. Ini berarti terdapat hubungan positif yang sangat signifikan antara religiusitas dengan penyesuaian diri pada menantu perempuan yang tinggal dengan ibu mertua, dengan demikian semakin tinggi tingkat religiusitas menantu perempuan semakin baik pula penyesuaian dirinya begitu pula sebaliknya.
\end{abstract}

Kata kunci: Penyesuaian Diri, Kematangan Emosi, Religiusitas

\title{
PENDAHULUAN
}

Pernikahan (marriage) pada umumnya berkaitan dengan suatu hubungan yang dijalani oleh pria dan wanita sebagai pasangan suami dan istri untuk menjadi satu keluarga baru, pada umumnya mereka yang masuk pada fase dewasa awal (young adulthood) yaitu dengan rentang usia antara 20-40 tahun (Papalia, Olds \& Feldman, 2009). Menurut Geertz (Sari, 2018) masyarakat Jawa konsep keluarga tidak hanya sebatas hubungan sedarah, akan tetapi adanya pelebaran hubungan yakni pernikahan.

Menurut Nugroho (Wigunawati, 2019) dalam budaya patriarki Jawa perempuan yang telah menikah akan mendapatkan sebutan suwarga nunut, neraka katut yang berarti seorang istri akan mengikuti kemanapun suami berada, suka tidak suka istri harus menurut dengan keputusan suami. Banyak pasangan yang mengawali pernikahannya ini harus tinggal di rumah 
mertua dengan aneka alasan, mulai dari kepraktisan hingga masalah ekonomi (Hanaco \& Wulandari, 2013).

Bagi masyarakat Barat, membebaskan anak-anaknya setelah menginjak usia 18 tahun adalah hal yang wajar. Akan aneh apabila orang dewasa setelah menikah masih tinggal serumah dengan orang tua. Berbanding terbalik di tanah air tercinta. Hubungan kekerabatan yang begitu kental bahkan masyarakat jawa sering terkesan menahan anak laki-laki setelah menikah untuk tetap tinggal dengan orang tua mereka karena dianggap sebagai pelindung apalagi apabila anak tersebut adalah anak laki-laki satu-satunya di dalam keluarga tersebut (Hanaco \& Wulandari, 2013). Menurut Lee (Sari, 2018) menantu yang tinggal bersama mertua disebut keluarga batih yang berarti keluarga inti yang dimasuki anggota keluarga lain. Fenomena menantu perempuan yang tinggal bersama mertua masih banyak ditemukan di masyarakat pedesaan.

Masa awal pernikahan merupakan pengalaman baru bagi seorang individu, maka biasanya pasangan baru sering mengalami ketegangan emosional, konflik dan perpecahan karena keduanya sedang dalam proses penyesuaian. Hurlock (2015) mengatakan bahwa pada usia awal pernikahan (rentang waktu antara satu sampai lima tahun pertama) merupakan masamasa rawan dan krisis dalam sebuah pernikahan. Karena pengalaman seorang pasangan tentang kehidupan barunya belum banyak, maka masa-masa ini merupakan masa penyesuaian antara dua karakter individu yang berbeda.

Menurut Desmita (2017) sebuah pernikahan menuntut adanya penyesuaian diri terhadap tuntutan peran dan tanggung jawab baru dari kedua pasangan. Selain menyesuaikan diri dengan pasangan, seseorang yang telah menikah harus mampu menyesuaikan diri dengan keluarga besar dari pasangannya, terutama di dalamnya adalah mertua. Hurlock (2015) menyebutkan terdapat empat jenis penyesuaian yang perlu dilakukan ketika seseorang individu menjalani hidup baru (menikah) yaitu penyesuaian terhadap pasangan, penyesuaian seksual, penyesuaian keuangan, dan penyesuaian dengan pihak keluarga pasangan. Bukan suatu hal yang mudah akan tetapi bukan berarti sulit atau mustahil. Banyak diluaran sana pasangan yang berhasil menyelaraskan keduanya dengan begitu indah (Hanaco \& Wulandari, 2013).

Ketidakmampuan menantu perempuan dalam menyesuaikan diri dengan ibu mertua dan begitu pula sebaliknya, merupakan penyebab dari konflik antara menantu dengan mertua. Pernikahan bisa jadi tidak akan mudah jika menantu mengalami kesulitan dalam menyesuaikan diri. Namun, sebaliknya pernikahan juga bisa menjadi semacam perjalanan yang 
menyenangkan jika berhasil menyesuaikan diri serta mengatasi segala hambatan yang ada di depan mata (Hanaco \& Wulandari, 2013). Apabila penyesuaian tersebut dapat berhasil maka kecil kemungkinan terjadi percekcokan dan ketegangan di dalamnya, selain itu dapat menimbulkan rasa stabil dan solider antara ibu mertua dengan menantu serta menciptakan kebersamaan dan kebahagiaan (Hurlock, 2015).

Individu bisa dikatakan mampu menyesuaikan diri apabila individu tersebut mampu menilai diri dan situasi secara objektif, mampu menerima tanggung jawab, mampu mengarahkan diri secara rasional, menjadikan pengalaman sebagai bahan pelajaran, memiliki mekanisme pertahanan diri dan coping stress yang baik, serta dapat mengontrol emosi (Fatimah, 2010). Menurut Schneiders (Yusuf, 2017) penyesuaian diri adalah usaha manusia untuk menguasai tekanan akibat dorongan kebutuhan, usaha memelihara keseimbangan antara pemenuhan kebutuhan dan tuntutan lingkungan, dan usaha menyelaraskan hubungan individu dengan realitas.

Hubungan antara penyesuaian dan perkembangan dapat berbeda-beda tergantung aspek perkembangan dan kematangan yang dicapai. Kondisi-kondisi itu seperti emosional, sosial, moral, keagamaan, intelektual dan dalam hal ini kematangan emosi merupakan yang terpenting dalam penyesuaian diri (Fatimah, 2010). Kematangan emosi dapat dikatakan sebagai suatu kondisi perasaan atau reaksi perasaan yang stabil terhadap suatu permasalahan sehingga individu yang matang dalam segi emosional akan selalu memakai pertimbangan sebagai dasar dalam mengambil keputusan atau bertingkah laku serta tidak mudah mengubah suasana hatinya dari suasana hati yang satu ke suasana hati yang (Hurlock, 2015).

Kematangan emosi memberikan pengaruh terhadap kemudahan melakukan penyesuaian diri dengan lingkungan. Dalam hal ini saat menantu perempuan sudah merasa dirinya matang dalam emosi, maka akan memberikan keyakinan bahwa dirinya dapat menyesuaikan diri dengan mudah dan mudah mengendalikan diri pada lingkungan baru (Fitroh, 2011). Hal tersebut dapat dilihat pada penelitian yang dilakukan oleh Anissa \& Handayani (2012), dengan judul "Hubungan Antara Konsep Diri dan Kematangan Emosi dengan Penyesuaian Diri Istri Yang Tinggal Bersama Keluarga Suami” menunjukkan adanya hubungan positif yang sangat signifikan antara kematangan emosi dengan penyesuaian yang ditunjukan dengan tingkat korelasi sebesar 0,336 dengan $\mathrm{p}=0,009$ ( $\mathrm{p}<0,01)$. Senada dengan penelitian yang dilakukan oleh Sharma (2017) yang berjudul "Effect of Emotional Maturity on Marital Adjustment of Women" diketahui bahwa istri atau menantu perempuan yang tergolong 
stabil dalam segi emosionalnya memiliki penyesuaian perkawinan yang baik daripada perempuan yang kurang stabil emosinya. Dengan demikian individu yang matang secara emosional akan mampu menyesuaikan diri dengan lingkungan, begitu sebaliknya.

Selain kematangan emosi, agama juga memegang peran penting dalam proses penyesuaian diri (Ali \& Asrori, 2019). Menurut Fatimah (2010) agama menciptakan suasana psikologis tertentu dalam mengurangi konflik, frustrasi dan ketegangan lainnya. Agama juga merupakan sumber nilai, norma, kepercayaan dan pola-pola tingkah laku yang akan memberikan tuntunan bagi arti, tujuan, serta kestabilan hidup yang dalam hal ini sembahyang dan berdoa menjadi medianya (Fatimah, 2010).

Subandi (2019) menyebutkan bahwa agama terdiri dari kesadaran beragama dan pengalaman agama. Menurut Subandi (2019) dalam agama tidak lepas dari konsep religiusitas atau keberagamaan karena religiusitas merupakan bagian dari religi atau agama yang telah diimplementasikan oleh individu dalam hati dan perilakunya. Menurut Jalaluddin (2007) religiusitas adalah suatu keadaan dalam diri individu yang mendorong untuk bertingkah laku dalam kehidupan sehari-hari yang berlandaskan oleh agama.

Penelitian yang dilakukan oleh Sedighi, Shahsiah \& Rasooli (2014) yang berjudul "The Relationship between Religious Orientation and Marital Adjustment among Couples of Qom City" diketahui bahwa religiusitas memiliki hubungan positif dengan penyesuaian diri dengan signifikansi $\mathrm{p}=0,05$. Artinya, semakin tinggi tingkat religiusitas individu maka semakin tinggi pula penyesuaian dirinya. Begitu sebaliknya semakin rendah tingkat religiusitas individu maka semakin rendah penyesuaian dirinya.

Berdasarkan uraian di atas dapat ditarik kesimpulan bahwa kematangan emosi seseorang begitu penting untuk seseorang dapat menyesuaikan diri dengan lingkungannya. Jika seseorang memiliki kematangan emosi yang tinggi maka seseorang akan mampu menyesuaikan diri dengan lingkungannya. Begitu juga dengan religiusitas seseorang, dimana seseorang yang memiliki religiusitas tinggi akan mampu menyesuaikan diri. Untuk itu penulis bermaksud melakukan penelitian yang bertujuan untuk mengetahui ada tidaknya hubungan antara kematangan emosi dan religiusitas dengan penyesuaian diri menantu perempuan yang tinggal dengan ibu mertua. 


\section{METODE}

Penelitian ini merupakan penelitian kuantitatif korelasional. Teknik pengambilan sampel dalam penelitian ini menggunakan teknik quota sampling, dimana pengambilan sampel dilakukan tanpa memandang strata atau wilayah tertentu melainkan berdasarkan jumlah tertentu yang telah ditentukan dengan memperhatikan karakteristik sesuai dengan permasalahan penelitian yang akan dilakukan (Prasetyo, 2005). Sampel yang digunakan dalam penelitian ini $n=50$ menantu perempuan yang tinggal dengan ibu mertua di Desa Kedungsari Kecamatan Gebog Kabupaten Kudus dengan rentang usia pernikahan satu sampai lima tahun dan beragama islam. Alasan pemilihan subjek beragama islam karena penelitian mengenai tingkat religiusitas agama islam yang dikaitkan dengan penyesuaian diri khususnya pada menantu perempuan yang tinggal dengan ibu mertua jarang ditemukan.

Metode pengumpulan data menggunakan tiga skala, yaitu skala penyesuaian diri, skala kematangan emosi, dan skala religiusitas. Skala penyesuaian diri mengacu pada aspek penyesuaian diri yang dikemukakan oleh Schneiders (Yusuf, 2004) yaitu; 1) kontrol emosi yang stabil, 2) tidak adanya mekanisme psikologis, 3) frustrasi personal yang minimal, 4) pertimbangan rasional dan kemampuan mengarahkan diri, 5) kemampuan untuk belajar, 6) memanfaatkan pengalaman masa lalu, 7) bersikap realistik dan objektif. Skala penyesuaian diri berjumlah 70 item yang mencakup 35 item favourable dan 35 item unfavourable.

Skala kematangan emosi mengacu pada aspek kematangan emosi yang dikemukakan oleh Walgito 2000) yaitu; 1) berpikir secara objektif, 2) tidak bersifat impulsif, 3) kontrol emosi, 4) bersifat sabar, 5) mempunyai tanggung jawab yang baik. Skala kematangan emosi berjumlah 50 item yang mencakup 25 item favourable dan 25 item unfavourable. Skala religiusitas mengacu pada dimensi religiusitas yang dikemukakan oleh Glock \& Stark (Ancok \& Suroso, 2011) yaitu; 1) dimensi keyakinan, 2) dimensi peribadatan atau praktek agama, 3) dimensi penghayatan, 4) dimensi pengalaman, 5) dimensi pengetahuan agama. Skala religiusitas berjumlah 50 item yang mencakup 25 item favourable dan 25 item unfavourable.

Data yang diperoleh dianalisis dengan menggunakan teknik statistika, yaitu Analisis Regresi Dua Prediktor. Dalam penelitian ini teknik Analisis Regresi Dua Prediktor dipakai untuk mencari ada tidaknya hubungan antara kematangan emosi dan religiusitas dengan penyesuaian diri menantu perempuan yang tinggal dengan ibu mertua, sedangkan metode untuk menguji hipotesis minor yaitu untuk mengetahui ada tidaknya hubungan antara kematangan emosi dengan penyesuaian diri menantu perempuan yang tinggal dengan ibu 
mertua dan untuk mengetahui ada tidaknya hubungan antara religiusitas dengan penyesuaian diri menantu perempuan yang tinggal dengan ibu mertua digunakan teknik Product Moment. Perhitungan analisis data menggunakan komputer dengan program Statistic Packages for Social Science (SPSS) 16,0 for windows.

\section{HASIL DAN PEMBAHASAN}

Pelaksanaan penelitian dilaksanakan pada tanggal 16 - 21 Januari 2021 di Desa Kedungsari Kecamatan Gebog Kabupaten Kudus, dengan responden berjumlah 50 menantu perempuan yang tinggal dengan ibu mertua dengan rentang usia pernikahan 1 sampai 5 tahun dan beragama islam. Pelaksanaan penelitian ini dilakukan dengan menggunakan try out ata terpakai yaitu data yang diperoleh dari try out atau uji coba sekaligus digunakan sebagai sumber data untuk penelitian data dilakukan uji analisis data. Teknik try out data terpakai ini dilakukan karena terbatasnya situasi dan kondisi karena pandemi Covid-19 yang mengharuskan social distancing.

Hasil penelitian disajikan dalam dua bagian, yaitu hasil uji asumsi dan hasil uji hipotesis. Uji asumsi yang dilakukan meliputi uji normalitas dan uji linieritas. Selanjutnya dilakukan pengujian hipotesis secara statistik.

Hasil uji asumsi yang pertama yaitu uji normalitas. Uji normalitas dilakukan untuk mengetahui apakah data yang digunakan dalam penelitian ini berdistribusi normal atau tidak. Uji normalitas menggunakan teknik statistik non parametrik One-Sample KolmogorovSmirnov Test. Data dikatakan berdistribusi normal apabila nilai signifikansi atau $\mathrm{p}>0,05$, sebaliknya apabila nilai $\mathrm{p}<0,05$ maka sebaran data dikatakan tidak normal. Hasil uji normalitas variabel kematangan emosi, religiusitas dan penyesuaian diri dapat dilihat pada tabel 1 .

Tabel 1

Hasil Analisis Uji Normalitas

\begin{tabular}{llllll}
\hline No & Variabel & $\mathbf{N}$ & $\begin{array}{l}\text { Kolmogorov- } \\
\text { Smirnov Test }\end{array}$ & Signifikansi (P) & Keterangan \\
\hline 1. & Kematangan emosi & 50 & 0,621 & 0,835 & Berdistribusi normal \\
\hline 2. & Religiusitas & 50 & 0,776 & 0,584 & Berdistribusi normal \\
\hline 3. & Penyesuaian diri & 50 & 0,986 & 0,286 & Berdistribusi normal \\
\hline
\end{tabular}

Berdasarkan hasil perhitungan uji normalitas seperti yang tersaji pada tabel diatas menunjukkan data-data sebagai berikut: pada variabel kematangan emosi diperoleh nilai 
signifikan atau $\mathrm{p}=0,835(\mathrm{p}>0,05)$ dan hasil kolmogorov-smirnov $\mathrm{Z}=0,621$. Berdasarkan hasil perolehan data tersebut menunjukkan bahwa variabel kematangan emosi berdistribusi normal. Kemudian pada variabel religiusitas diperoleh signifikan atau $p=0,584(p>0,05)$ dan hasil kolmogorov-smirnov $\mathrm{Z}=0,776$. Berdasarkan hasil perolehan data tersebut menunjukkan bahwa variabel religiusitas berdistribusi normal. Selanjutnya pada variabel penyesuaian diri diperoleh signifikan atau $\mathrm{p}=0,286(\mathrm{p}>0,05)$ dan hasil kolmogorov-smirnov $\mathrm{Z}=0,986$. Berdasarkan hasil perolehan data tersebut menunjukkan bahwa variabel penyesuaian diri berdistribusi normal.

Hasil uji asumsi yang kedua yaitu uji linieritas. Uji linieritas merupakan suatu prosedur yang digunakan untuk mengetahui status linear atau tidaknya suatu distribusi data penelitian. Hasil uji asumsi hubungan antara penyesuaian diri dengan kematangan emosi dapat dilihat pada tabel 2.

Tabel 2

Hasil Analisis Uji Linieritas Penyesuaian Diri Dengan Kematangan Emosi

\begin{tabular}{lllll}
\hline No & Variabel & F & Signifikansi $(\mathrm{p})$ & Keterangan \\
\hline 1. & $\begin{array}{l}\text { Penyesuaian diri dengan kematangan } \\
\text { emosi }\end{array}$ & 1,136 & 0,375 & Linier \\
\hline
\end{tabular}

Berdasarkan pada hasil perhitungan uji linieritas seperti yang tersaji pada tabel diatas menunjukkan bahwa hubungan antara penyesuaian diri dengan kematangan emosi adalah linier. Hal ini terbukti dengan signifikan $\mathrm{p}=0,375$ atau $\mathrm{p}>0,05$ dan nilai $\mathrm{F}$ linier $=1,136$. Selanjutnya untuk mengetahui hasil uji linieritas penyesuaian diri dengan religiusitas dapat dilihat pada tabel 3 .

Tabel 3

Hasil Analisis Uji Linieritas Penyesuaian Diri Dengan Religiusitas

\begin{tabular}{lllll}
\hline No & Variabel & F & Signifikansi $(\mathrm{p})$ & Keterangan \\
\hline 1. & Penyesuaian diri dengan religiusitas & 1,788 & 0,077 & Linier \\
\hline
\end{tabular}

Berdasarkan pada hasil perhitungan uji linieritas seperti yang tersaji pada tabel di atas menunjukkan bahwa hubungan antara penyesuaian diri dengan religiusitas adalah linier hal ini terbukti dengan signifikan $\mathrm{p}=0,077$ atau $\mathrm{p}>0,05$ dan nilai $\mathrm{F}$ linier $=1,788$.

Hipotesis dalam penelitian ini adalah ada hubungan antara kematangan emosi dan religiusitas dengan penyesuaian diri pada menantu perempuan yang tinggal dengan ibu mertua. Hasil analisis regresi dua prediktor dapat dilihat pada tabel 4. 
Tabel 4

Hasil Analisis Regresi Berganda Kematangan Emosi dan Religiusitas dengan Penyesuaian Diri

\begin{tabular}{lllll}
\hline No & rx 1,2y & R2 & F & Signifikansi (p) \\
\hline 1. & 0,810 & 0,657 & 44,967 & 0,000 \\
\hline
\end{tabular}

Berdasarkan hasil perhitungan uji hipotesis mayor di atas diperoleh nilai koefisien korelasi dari ketiga variabel yaitu $\mathrm{rx} 1,2 \mathrm{y}=0,810$ dengan nilai $\mathrm{p}=0,000$ atau $\mathrm{p}<0,01$. Berdasarkan hasil analisis regresi tersebut menunjukkan bahwa terdapat hubungan yang sangat signifikan antara kematangan emosi dan religiusitas dengan penyesuaian diri pada menantu perempuan yang tinggal dengan ibu mertua. Adapun sumbangan efektif variabel kematangan emosi dan religiusitas dengan penyesuaian diri sebesar $65,7 \%$ dan $34,3 \%$ dipengaruhi oleh faktor lain.

Hasil uji hipotesis mayor yang telah dilakukan dalam penelitian ini diperkuat dengan hasil uji hipotesis minor yang pertama, yaitu analisis korelasi antara kematangan emosi dengan penyesuaian diri. Uji hipotesis untuk membuktikan adanya hubungan positif antara kematangan emosi dengan penyesuaian diri digunakan analisis korelasi product moment. Hasil analisis korelasi product moment dapat dilihat pada tabel 5.

Tabel 5

Hasil analisis korelasi penyesuaian diri dengan kematangan emosi

\begin{tabular}{lllll}
\hline No & Variabel & Rx1y & R squared & Signifikansi (p) \\
\hline 1. & $\begin{array}{l}\text { Penyesuaian diri dengan kematangan } \\
\text { emosi }\end{array}$ & 0,810 & 0,655 & 0,000 \\
\hline
\end{tabular}

Sesuai dengan hasil perhitungan diatas diperoleh nilai koefisien korelasi dari variabel kematangan emosi dengan penyesuaian diri $(\mathrm{rx} 1 \mathrm{y}=0.810)$, dengan nilai $\mathrm{p}$ sebesar 0,000 atau $\mathrm{p}<0,001$. Berdasarkan hasil analisis korelasi product moment tersebut menunjukkan bahwa terdapat hubungan positif yang sangat signifikan antara kematangan emosi dengan penyesuaian diri pada menantu perempuan yang tinggal dengan ibu mertua. Adapun besarnya sumbangan efektif dari variabel kematangan emosi dengan penyesuaian diri sebesar 65,5\%. Hal tersebut menunjukkan bahwa semakin tinggi kematangan emosi maka semakin tinggi tingkat penyesuaian diri pada menantu perempuan yang tinggal dengan ibu mertua. Demikian pula sebaliknya semakin rendah kematangan emosi maka semakin rendah tingkat penyesuaian diri. 
Hasil penelitian tersebut senada dengan hasil penelitian yang dilakukan oleh Senejani, dkk (2016) dengan judul "Examining The Relationship Between Psychological Security, Emotional Maturity, and Attachment Styles and Marital Adjustment" menunjukkan adanya hubungan positif yang signifikan antara kematangan emosi dengan penyesuaian pernikahan. Adapun penelitian lain dari Sheeeja, dkk (2020) dengan judul "Study On The Effect Of Emotional Maturity On Marital Adjustment Among Couples In Kerala” menunjukkan bahwa kematangan emosi berpengaruh secara positif terhadap penyesuaian pernikahan. Itu artinya semakin baik kematangan emosi individu maka semakin baik penyesuaian dirinya.

Hasil perhitungan uji hipotesis minor kedua yaitu adanya hubungan positif antara religiusitas dengan penyesuaian diri. Uji hipotesis untuk membuktikan adanya hubungan positif antara religiusitas dengan penyesuaian diri digunakan analisis korelasi product moment. Hasil analisis korelasi product moment dapat dilihat pada tabel 6.

Tabel 4.12

Hasil Analisis Korelasi Penyesuaian Diri dengan Religiusitas

\begin{tabular}{lllll}
\hline No & Variabel & Rx2y & R squared & Signifikansi (p) \\
\hline 1. & Penyesuaian diri dengan religiusitas & 0,636 & 0,404 & 0,000 \\
\hline
\end{tabular}

Sesuai dengan hasil perhitungan di atas diperoleh nilai koefisien korelasi dari variabel religiusitas dengan penyesuaian diri $(\mathrm{rx} 2 \mathrm{y}=0,636)$ dengan nilai $\mathrm{p}$ sebesar 0,000 atau $\mathrm{p}<0,01$. Berdasarkan hasil analisis korelasi product moment tersebut menunjukkan bahwa terdapat hubungan positif yang sangat signifikan antara religiusitas dengan penyesuaian diri pada menantu perempuan yang tinggal dengan ibu mertua. Adapun besarnya sumbangan efektif dari variabel religiusitas dengan penyesuaian diri sebesar 40,4\%. Hasil tersebut menunjukkan bahwa semakin tinggi religiusitas maka semakin tinggi penyesuaian diri pada menantu perempuan yang tinggal dengan ibu mertua. Demikian sebaliknya semakin rendah religiusitas maka semakin rendah penyesuaian diri pada menantu perempuan yang tinggal dengan ibu mertua.

Hasil tersebut senada dengan hasil penelitian yang pernah dilakukan oleh Yeganeh \& Shaikhmahmoodi (2013) dengan judul "Role Of Religious Orientation In Predicting Marital Adjustment and Psychological Well-Being” menunjukkan adanya hubungan positif antara religiusitas dengan penyesuaian perkawinan. Penelitian lain oleh McDonald dkk (2017) dengan judul "Effects Of Religiosity, Forgiveness and Spousal Empathy On Marital Adjustment" menunjukkan bahwa religiusitas berpengaruh secara positif terhadap penyesuaian perkawinan 
pada wanita Amerika-Eropa. Itu artinya semakin tinggi religiusitas individu maka semakin baik penyesuaian dirinya.

\section{SIMPULAN}

Berdasarkan hasil analisis data yang telah dilakukan menunjukkan hasil yaitu rx1,2y = 0,810 dengan nilai $\mathrm{p}=0,000$ atau $\mathrm{p}<0,01$. Hasil tersebut menunjukkan bahwa terdapat hubungan yang sangat signifikan antara kematangan emosi dan religiusitas dengan penyesuaian diri pada menantu perempuan yang tinggal dengan ibu mertua. Adapun sumbangan efektif variabel kematangan emosi dan religiusitas dengan penyesuaian diri sebesar $65,7 \%$.

Saran bagi peneliti selanjutnya hendaknya dapat menyempurnakan hasil penelitian ini dengan melakukan penelitian yang bersudut pandang ibu mertua sebagai subjek penelitian, selain itu hendaknya penyempurnaan item, dapat melakukan perluasan populasi, serta dapat melibatkan pengaruh faktor-faktor lain selain kematangan emosi dan religiusitas.

\section{DAFTAR PUSTAKA}

Ali, M \& Asrori, M. (2019). Psikologi Remaja Perkembangan Peserta Didik. Jakarta : Bumi Aksara.

Ancok, D \& Suroso, F.N. (2005). Psikologi Islam: Solusi Islam atas problem-problem psikologi. Yogyakarta: Pustaka Pelajar.

Anissa, N \& Handayani, A. (2012). Hubungan Antara Konsep Diri dan Kematangan Emosi dengan Penyesuaian Diri Istri yang Tinggal Bersama Keluarga Suami. Jurnal Psikologi Pitutur. Vol 1. No 1.

Desmita. (2017). Psikologi Perkembangan Peserta Didik. Bandung: Remaja Rosdakarya.

Fatimah, E. (2010). Psikologi Perkermbangan (Perkembangan Peserta Didik). Bandung : Pustaka Setia.

Fitroh, S. F. (2011). Hubungan Antara Kematangan Emosi dan Hardiness dengan Penyesuaian Diri Menantu yang Tinggal di Rumah Ibu Mertua. Jurnal Psikologi Islam. Vol, 2, No. 1201183-98.

Hanaco, I \& Wulandari, A. (2013). Disayang Mertua, Mesra Dengan Menantu, Mesra dalam Keluarga. Yogyakarta : Penerbit ANDI 
Hurlock, E. B. (2015). Psikologi Perkembangan (Suatu Pendekatan Sepanjang Rentang Kehidupan) Edisi kelima. Alih Bahasa : Drs. Istiwidayanti. Jakarta: Erlangga.

Jalaluddin, R. (2007). Psikologi Agama: Memahami Perilaku Keagamaan Dengan Mengaplikasikan Prinsip-Prinsip Psikologi. Jakarta: PT Rajagrafindo Persada.

McDonald, J. E., Olson, J. R., Lanning, A. H., Goddard, H. W., \& Marshall, J. P. (2017). Effects of Religiosity, Forgiveness, and Spousal Empathy on Marital Adjustment. Marriage \& Family Review.

Papalia, D. E., Old s, S. W., \& Feldman, R. D. (2009). Human Development Perkembangan Manusia, Jakarta : Salemba Humanika.

Prasetyo, B. 2005. Metode Penelitian Kuantitatif. Jakarta : Raja Grafindo Persada

Sari, D. P. (2018). Dinamika Relasi Menantu Dengan Mertua Yang Tinggal Bersama. Skripsi. Yogyakarta: Fakultas Psikologi Universitas Sanata Dharma.

Sedighi, F., Shahsiah, M., \& Rasool, A. (2014).The Relationship between Religious Orientation and Marital Adjustment among Couples of Qom City. Journal of Applied Environmental and Biological Sciences. Vol 4(3).

Senejani, M. J., Dast, T. T., \& Farhangi, A. H. (2016). Examining the Relationship Between Psychological Security, Emotional Maturity, and Attachment Style and Marital Adjustment. International Journal of Medical Research \& Health Sciences

Sharma, A. (2017). Effect of Emotional Maturity on Marital Adjustment of Women. Journal Global Values. Vol. VIII, No.2, Article No. 8, pp.56-60.

Sheeeja, K. F., Arunmozhi, A., \& Francis, N, M. (2020). Study on the effect of Emotional Maturity on Marital Adjustment among Couples in Kerala. Journal of Critical Review. Vol 7.

Subandi, M. A. (2019). Psikologi Agama \& Kesehatan Mental. Yogyakarta: Pustaka Pelajar.

Walgito, B. (2000). Bimbingan \& Konseling Perkawinan. Yogyakarta: Andi Offset.

Wigunawati, E. (2019). Penyesuaian Diri Ibu Mertua Terhadap Menantu Perempuan Yang Tinggal Bersama Di Awal Pernikahan Pada Budaya Jawa. Jurnal Inada. Vol 2. No 2.

Yeganeh, T \& Shaikhmahmoodi, H. (2013). Role of Religious Orientation in Predicting Marital Adjustment and Psychological Well-Being. Sociology Mind. Vol 3. No 2.

Yusuf, S. (2004). Mental Hygiene Perkembangan Kesehatan Mental dalam Kajian Psikologi dan Agama. Bandung : Pustaka Bani Quraisy. 